\title{
APLICATION OF STATISTICS METHODS IN TECHING OF TECHNICAL SUBJECTS
}

\section{Josef ŠEDIVÝ}

\begin{abstract}
In the article the author shows the didactic possibility of statistics method application in the teaching of technical subjects. Scientific statistics methods and their application by means of information technology aks for greated attention of the teachers of technical subjects. It should be already from the secondary schools a current part of the evalution and elaboration of students measurements, experiences, researches and projects.
\end{abstract}

Key wodrs: Information skills, teaching process of technical subjects, aplication of statistics methods.

\section{APLIKACE STATISTICKÝCH METOD DO VÝUKY TECHNICKÝCH PŘEDMĚTŮ}

Resumé: V př́spěvku autor poukazuje na didaktické možnosti aplikace statistických metod ve výuce technických předmètù. Statistické analytické metody a jejich aplikace pomocí informační technologie si zaslouži větši pozornost učitelů technických predmětù. Měly by se stát již od střední školy běžnou součástí vyhodnoceni a zpracováni studentských měrení, pokusủ, výzkumů a projektů.

Klićová slova: informačni gramotnost, výuka technických předmětůu, aplikace statistických metod.

\section{1 Úvod}

Aplikovaná informační gramotnost se dnes uvádí mezi hlavními cíli nejen technického vzdělávání. Tento cíl není jako dříve př́sně vázán na konkrétní obsahy učiva. Dosud se hledá v operacionalizovaném popisu tohoto cíle mezi odborníky shoda. Aplikovaná informační gramotnost je např́iklad podmínkou ukončení studia na univerzitách v USA. Dá se však získat jedině aktivní činností, ne opisováním a memorováním faktů. Při výuce podporující informační gramotnost je faktem, že obsahy učebních předmětů poněkud ustupují do pozadí. Nehrají už dřívější primární roli. Je dokonce vhodné redukovat rozsah učiva. Informační gramotnost už dnes zahrnována do kurikula mnoha škol. Často ale chybí upřesnit konkrétní aplikace informační kompetencí na daném stupni školy a jejich nutný rozsah. Ve školní praxi se tak neobejdeme ani bez vyškolení všech učitelů $\mathrm{k}$ problematice informační gramotnosti. Je třeba stanovit jisté indikátory kvality, kdy informatické činnosti hodnotíme jako vyhovující. Tím můžeme jakýsi výkonový standard ( Turek, 2002)

\section{Statistické metody ve výuce technických předmětů}

Podmínkou vhodného aplikace statistických metod $\quad \mathrm{v}$ technických a prírodovědných měřeních je sledování, zda se sledovaný proces chová „,normálně“, tj. že na něj působí pouze náhodné (neovlivnitelné) příčiny, nebo zda působí i jasně popsané a vymezitelné příčiny a vlivy. Pak je možné na základě informace plynoucí ze statistiky zasáhnout, tj. př́íčiny identifikovat a je-li to možné i odstranit. Náhodné př́íciny jsou každému procesu v reálných podmínkách vlastní, jedná se např. o obvyklou proměnlivost. Takových př́čin může být pochopitelně velké množství a žádná z nich nemusí sama o sobě být schopna rozkolísat proces nijak podstatnou měrou. $Z$ toho plyne, že účinek náhodných příčin na proces nelze dobře měřit, a protože jsou tyto i velmi těžko ovlivnitelné, nemá mnohdy ani smysl jej identifikovat. Maximální možnou míru informací např. o probíhajícím fyzikálním procesu nebo jevu dnes získáme vyhodnocením na počítači za pomoci souboru analytických statistických metod, které je možné $\mathrm{v}$ přiměřené formě aplikovat př́mo ve výuce.

Technologický pokrok zpracování informací potvrdil platnost obecně zásad inženýrské pedagogiky a přinesl hardwarové i softwarové prostředky k rychlé a efektivní realizaci.

Statistiku v hodinách technických předmětů dobře využijeme pro vyhodnocení procesů a měření.

Aplikace statistických metod je perspektivní obor na pomezí vědních disciplín, statistiky a informatiky. 


\section{Paretủv diagram}

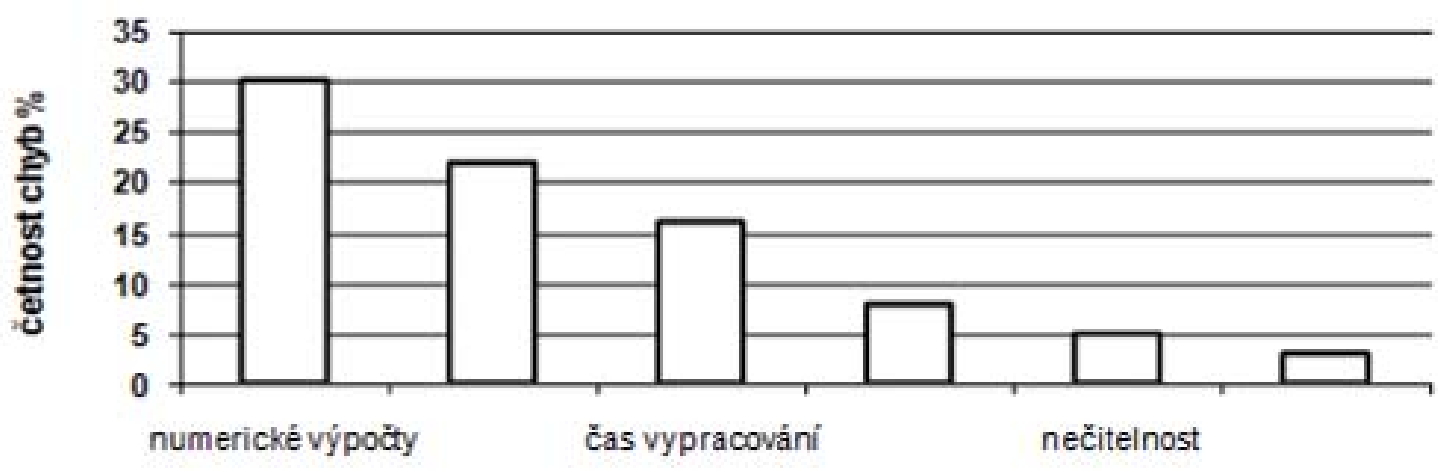

Obr. 1: Paretưv diagram (ve statistických programech nazýván Paretova analýza) použitý zde pro vizualizaci četnosti chyb v písemném testu.

Úvodní učební program nebo základní kurz není s výjimkou vysokoškolských specializovaných volitelných předmětů koncipován. Přitom vybavenost laboratoří informačními technologiemi umožňuje použití specializovaných softwarů, které výborně vyhovují moderním zásadám inženýrské pedagogiky a didaktiky (vizualizace, analýza, transfer, strukturování dat). Při dnešní rychlosti zpracování dat je významnou výhodou počítačů rychlá manipulace sreprezentacemi dat, možnost různě je transformovat a pružně měnit podmínky takových reprezentací. Každá samostatná seminární práce, každý studentský projekt i každá hodina technické výuky mají obsahovat tvưrčí hypotézy (Turek, I. 1996, s 6.). Student odborného předmětu by měl být vybaven elementárním souborem metod s vědeckým základem, hypotézu vyhodnotit a vyjádřit vlastní úsudek. Přes určitou nepopularitu statistiky se přitom nejedná o disciplínu s vysokou úrovní vstupních znalostí.

Jako př́klad uvádím pro učitele užitečný Paretův diagram. Ten uspořádává jednotlivé vlivy, které se podílejí na dané konkrétní situaci či problému. Podstatné je uvedení $\mathrm{v}$ pořadí podle významu, které položky mají. Rozdělujeme sledované znaky na podstatné, kterých je spíše málo a na nepodstatné, kterých může být naopak velmi mnoho. Ty marginální vlastně vůbec neuvádíme. (Studenti mnohdy vymyslí na kontrolní dotaz vlivy až absurdní.)

Paretova analýza je přes svoji jednoduchost kterou vidíte na prripojeném obr. 1. jedním z velmi důležitých rozhodovacích nástrojů Díky této analýze se pedagogovi dostávají potřebné informace, které umožňují soustředit pozornost ve výuce na podstatné problémové okruhy a úsilí věnovat oblastem, které jsou významné a přinesou největší efekty.

\section{Závěr}

Účinné odborné vyučování lze dnes realizovat pouze $\mathrm{v}$ prostředí, kdy učiníme z informační technologie běžnou součást pedagogické komunikace (Bertrand, Y., 1998 s. 100). Možnosti, které nabízejí statistické metody v technickém vyučování jsou rozmanité a zatím na své plné využití čekají. V současné praxi mizí ostré hranice mezi klasickými vědními obory, moderní výuka proto podporuje mezioborové transfery (právě statistická analýza pomohla vzniku specializovaných oborů jako technometrie, chemometrie apod.). Měníme priority výuky, do popředí vystupuje metodika a systematika vědecké práce.

Osvojení analytických metod s vědeckými základy se tak $\mathrm{v}$ současnosti musí zařadit mezi priority vzdělávání.

\section{Literatura:}

(1) Bertrand, Y.: Soudobé teorie vzdělávání, Portál : Praha, 1998, 247s. ISBN 80-7178-2165.

(2) Turek, I.: Učitel a tvorivost', Metodické centrum města Bratislavy : Bratislava, 1996, 88s. ISBN 80-7164-150-2.

(3) Turek, I.: Informačná gramotnost', in Technológia vzdelavania, 2002, roč. X, č. 4. s. 3-9. ISSN1335-003X.
Ing. Mgr. Josef Šedivý,
PdF UHK,
E-mail: sedivy.josef@atlas.cz 